\title{
Mechanisms of Biliary Plastic Stent Occlusion and Efforts at Prevention
}

\author{
Chang-II Kwon ${ }^{1}$ and Glen A. Lehman ${ }^{2}$ \\ ${ }^{1}$ Digestive Disease Center, CHA Bundang Medical Center, CHA University, Seongnam, Korea, ${ }^{2}$ Division of Gastroenterology and Hepatology, \\ Indiana University School of Medicine, Indianapolis, IN, USA
}

Biliary stenting via endoscopic retrograde cholangiopancreatography has greatly improved the quality of patient care over the last 30 years. Plastic stent occlusion limits the life span of such stents. Attempts to improve plastic stent patency duration have mostly failed. Metal stents (self-expandable metal stents [SEMSs]) have therefore replaced plastic stents, especially for malignant biliary strictures. SEMS are at least 10 times more expensive than plastic stents. In this focused review, we will discuss basic mechanisms of plastic stent occlusion, along with a systematic summary of previous efforts and related studies to improve stent patency and potential new techniques to overcome existing limitations. Clin Endosc 2016;49:139-146

Key Words: Stents; Biliary tract; Occlusion; Patency; Biofilms

\section{INTRODUCTION}

One of the most remarkable achievements in the history of therapeutic pancreatobiliary endoscopy is the introduction of biliary stent placement to prevent obstruction during endoscopic retrograde cholangiopancreatography (ERCP). This has become established as a treatment to resolve obstructive jaundice by a non-surgical approach. As this technique allows the relief of preoperative acute biliary obstruction, it is useful for stabilizing patients before surgery and enhancing their quality of life by enabling internal drainage in those who are not eligible for surgery. ${ }^{1,2}$

The main disadvantage of plastic stents is their limited diameter. This is set by the working channel in the duodenoscope, which prevents use of plastic stents with an outer

Received: January 18, 2016 Revised: February 2, 2016

Accepted: February 2, 2016

Correspondence: Glen A. Lehman

Division of Gastroenterology and Hepatology, Indiana University Hospital, 550

North University Blvd., Suite 1634, Indianapolis, IN 46202-5149, USA

Tel: +1-317-944-4824, Fax: +1-317-948-0164, E-mail: glehman@iu.edu

cc This is an Open Access article distributed under the terms of the Creative Commons Attribution Non-Commercial License (http://creativecommons.org/ licenses/by-nc/3.0) which permits unrestricted non-commercial use, distribution, and reproduction in any medium, provided the original work is properly cited. diameter of more than $12 \mathrm{Fr}^{3}$ This is not a major problem for patients who only require temporary stent placement, but can be a major issue for patients who require long-term placement of a stent. Patients with early stent occlusion before scheduled replacement can experience sudden obstruction of bile flow and complain of symptoms of recurrent biliary obstruction. This can also lead to acute cholangitis and sepsis, which can be life-threatening. Frequent stent replacement also increases medical costs and reduces the quality of life of patients with general illness.

In this focused review, we will discuss mechanisms of plastic stent occlusion, along with a summary of previous efforts and related studies to improve stent patency, and potential new techniques to overcome existing limitations.

\section{MECHANISMS OF BILIARY STENT OCCLUSION}

Biliary plastic stents were first introduced in 1979, and the mechanisms of biliary stent occlusion were thoroughly investigated 20 to 30 years ago. ${ }^{4}$ Early stent occlusion within 30 days, although very rare, mostly occurred due to positioning error, blood clots, debris, or mucus from a mucin-producing 
tumor. ${ }^{5}$ This review will focus on late stent occlusion $(\geq 30$ days post-placement).

The widely-accepted theory is that bacterial biofilm and biliary sludge both play major roles, along with the extent of bacterial infection and duodenobiliary reflux of dietary fiber. ${ }^{3,6-8}$ Biliary sludge is different from cholesterol-rich sludge, which is generally related to gallstone formation. The biliary sludge that causes stent occlusion is mainly composed of crystals of calcium bilirubinate and calcium palmitate formed by bacterial enzymes. ${ }^{6-12}$ It is also known that several types of proteins (such as fibronectin, vitronectin, laminin, fibrin, and collagen), which are derived from bacteria of unknown specific origin but are not naturally present in bile, form a conditioning film, making the bacteria more adhesive, and also work with the bacteria to produce biliary sludge. ${ }^{13-17}$ The formation of a biofilm that occurs as a result of attachment of these proteins onto the inner surface of a stent is known to play a major role in the initiation of sludge accumulation, but its exact role in the process of stent occlusion is still unknown.

\section{THE ROLE OF BACTERIAL COLONIZATION IN STENT OCCLUSION}

The most important factor in the process of stent occlusion is bacterial colonization. Micro-organisms isolated from occluded biliary stents include anaerobic bacterial species, fungi, and aerobic bacterial species. The gram-positive Enterococcus species, and gram-negative Escherichia coli and Klebsiella species are most commonly encountered among aerobic bacteria, with Clostridium species among anaerobic bacteria. The species identified vary greatly among reported series, possibly affected by sites where stents were implanted, time to test after removal, interval antibiotic use, and inadequate techniques to identify anaerobic species. In any case, the synergistic effect between bacterial adherence and biofilm formation caused by these bacteria is known to trigger stent obstruction. Studies have suggested that stent patency may vary depending on the types of bacteria or the types of byproducts and proteins released by different bacteria. Other studies on scanning electron microscopy (SEM) have suggested that biofilm thickness may vary depending on their combined action. ${ }^{18}$

\section{SCANNING ELECTRON MICROSCOPY EXAMINATIONS}

Biofilms generally do not become thick enough to cause complete stent occlusion. Removed biliary plastic stents evaluated by longitudinal sectioning show a less than $0.5-\mathrm{mm}$ -
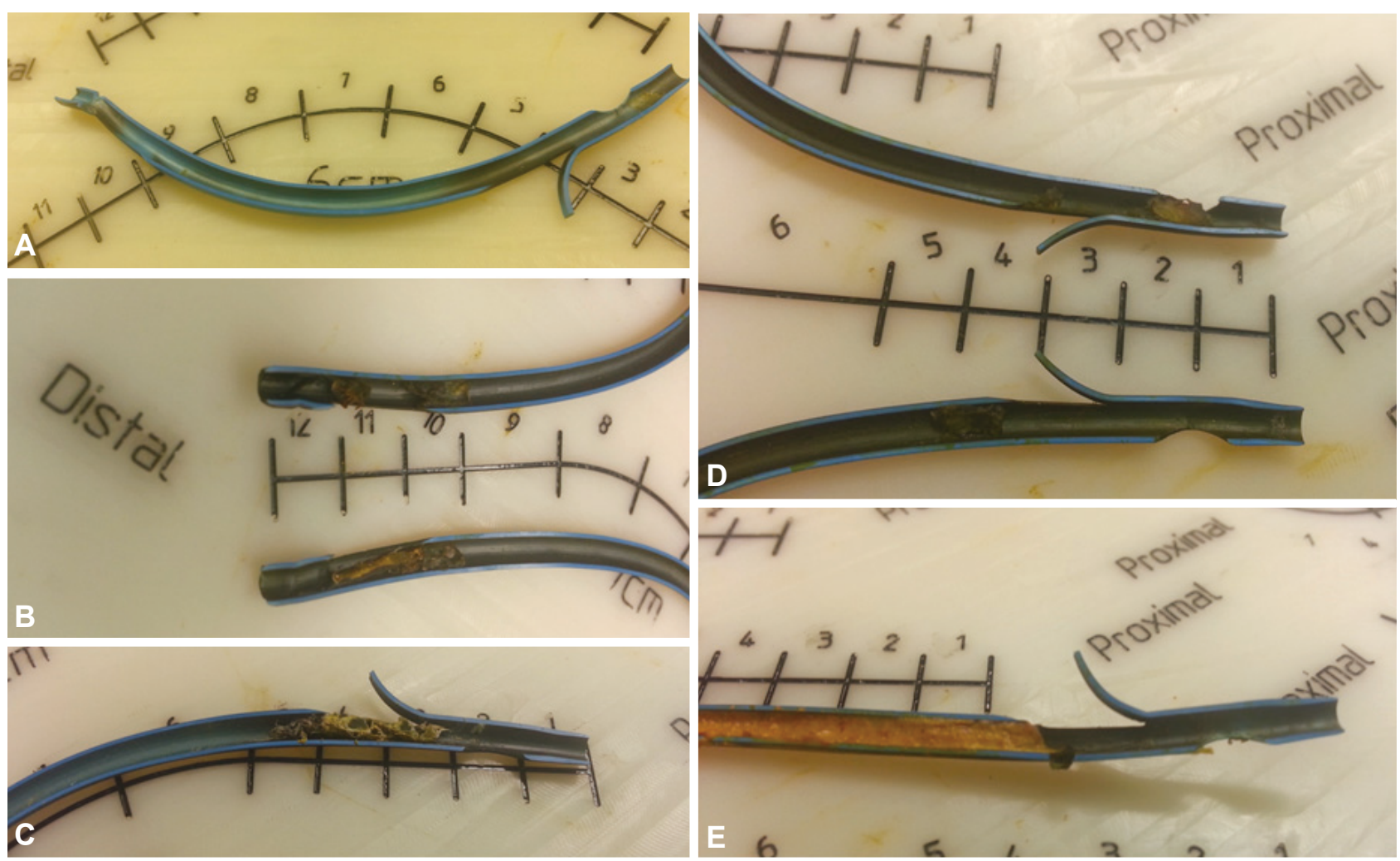

Fig. 1. (A-E) Retrieved biliary plastic stents with the inner layer exposed by longitudinal cutting. The dark greenish biofilms do not contribute significantly to increased thickness of the occluded inner layer. Stent occlusion is mostly caused by debris, sludge, and food components. 

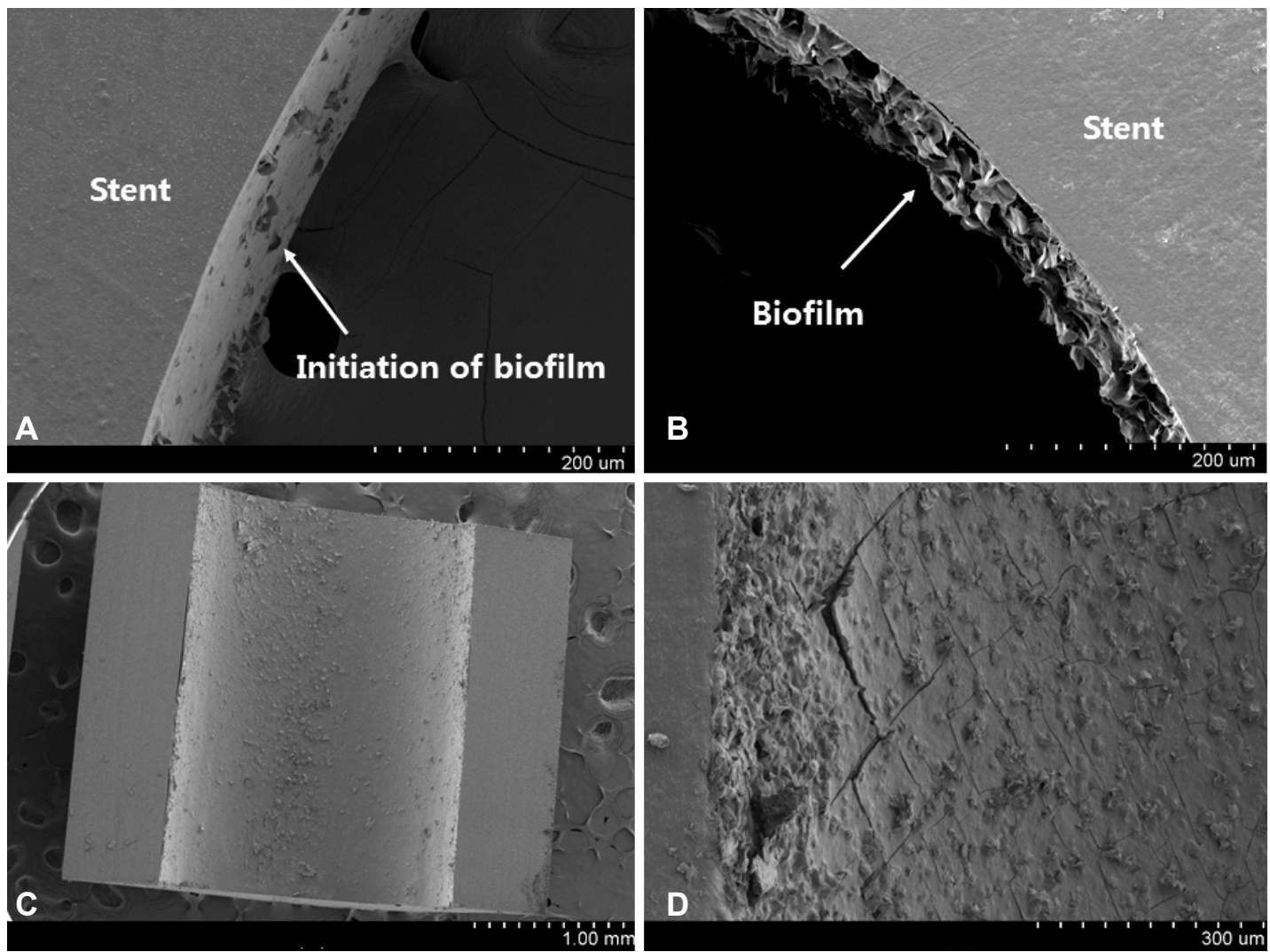

Fig. 2. Scanning electron microscopy (SEM) examination of stent occlusion. SEM images of the inner surface of a stent retrieved at about 4 weeks. The biofilm starts to appear on the inner surface of the stent $(A, \times 250)$. The biofilm itself becomes gradually thicker relatively evenly $(B, \times 250 ; C, \times 30)$. The surface becomes more solid and cracked in some areas $(D, \times 150)$.

thick inner layer of biofilm; the occlusion is mostly caused by debris, sludge, and food components (Fig. 1).

A SEM examination of stents revealed interesting facts in terms of the change in biofilm depending on the time they were retrieved. Fig. 2 shows the inner surface of a stent retrieved approximately 4 weeks after implantation. The biofilm starts to appear on the inner surface of the stent (Fig. 2A); the biofilm itself becomes gradually thicker relatively evenly, and the surface becomes more solid (Fig. 2B-D). Fig. 3 shows the inside of a stent retrieved approximately 8 weeks after implantation. Sludge covers the biofilm, rapidly narrowing the inner diameter of the stent (Fig. 3A-C). It also appears that debris, presumably derived from causes other than sludge, is attached to the inner layer of the stent without the sludge (Fig. 3D).

What this suggests is that the biofilm is associated with the initiation of stent occlusion but that overall thickening of the biofilm is not the cause of total occlusion. It may be possible that a biofilm on the inner surface of a stent can make the surface irregular, facilitating the accumulation of sludge or debris. Various biological factors mentioned above and a number of physical factors (such as stent shapes, side holes, duodenobiliary reflux of different food components, inner coating status, bile composition status due to underlying disease, and preexisting cholelithiasis) are also thought to work together to promote sludge attachment to the inner layer. To date, antibiotics to inhibit the formation of biofilm have not improved stent patency.

\section{METHODS FOR PREVENTION OF PLASTIC STENT OCCLUSION}

\section{Stent diameter}

Stents with a larger diameter have longer patency because it takes longer for the inner cavity to fill with foreign substances. ${ }^{19}$ However, it is impossible to endlessly extend the diameter of the working channel of an endoscope due to its design, and thus the maximum outer diameter of a plastic stent is $11.5 \mathrm{Fr}$ at most. Then 10-Fr plastic stents require a duodenoscope with an accessory channel of $3.7 \mathrm{~mm}$, and 11.5-Fr plastic stents require a duodenoscope with an accessory channel of $4.2 \mathrm{~mm} .{ }^{20}$ However, prospective studies found no major difference in the outcome between 10- and 11.5-Fr stents, and the mean duration of stent patency was 3 to 6 months. ${ }^{3,21-23}$ 

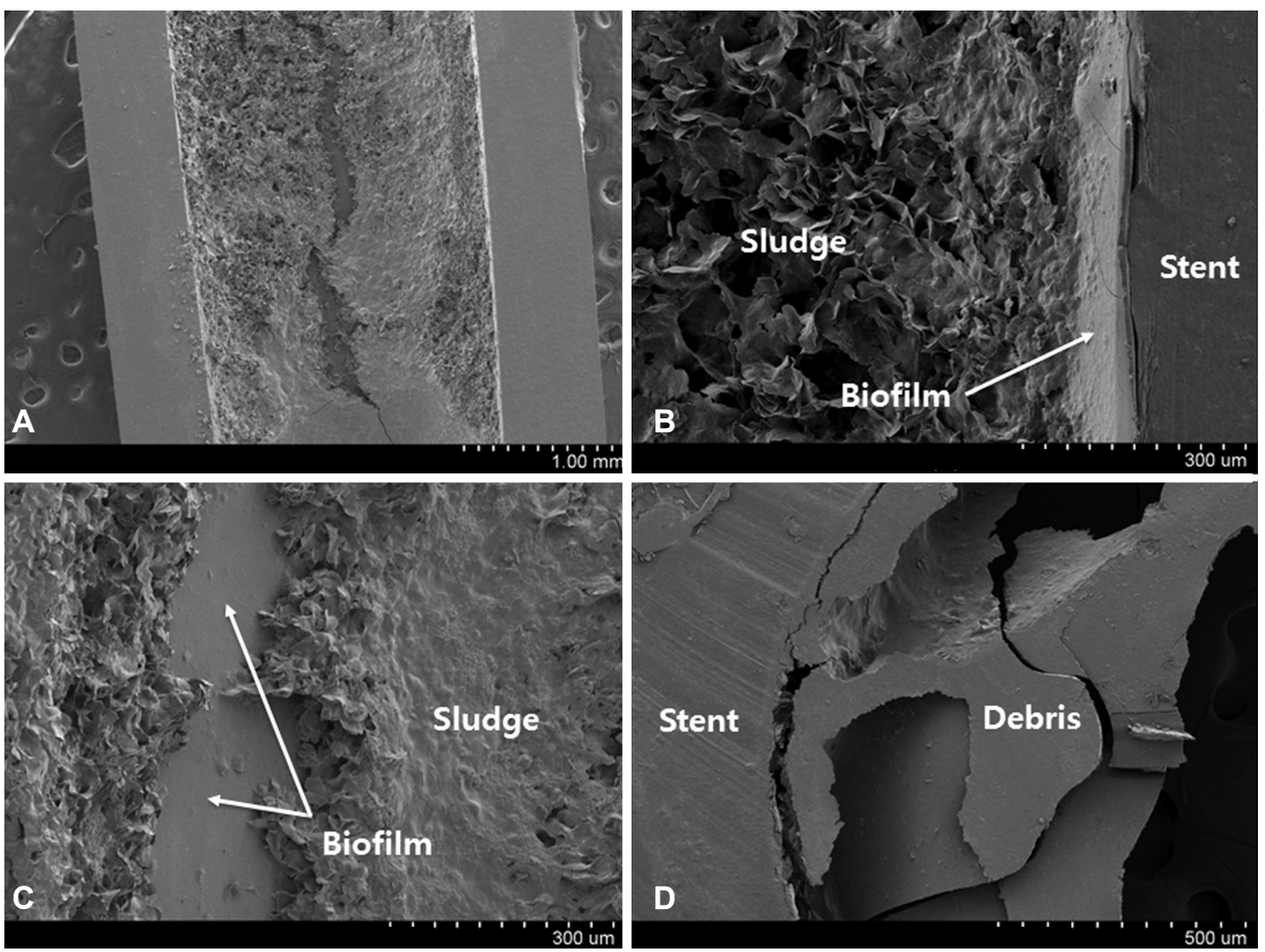

Fig. 3. Scanning electron microscopy (SEM) examination of stent occlusion. SEM images of the inner surface of a stent retrieved at about 8 weeks. Sludge covers the biofilm and narrows the inner diameter of the stent $(A, \times 30 ; B, \times 150)$. The biofilm is exposed in some areas that are not covered by sludge $(C, \times 150)$. Debris, presumably derived from other causes even before the formation of the biofilm, is attached to the inner layer of the stent $(D, \times 100)$.

Studies evaluating thinner-walled stents with the same outer diameter, and the use of single versus multiple plastic stents are needed.

\section{Stent composition and shape}

One can assume that the composition or shape of plastic stents might affect stent patency; however, previous studies have suggested that patency was not significantly affected by composition (Teflon, polyurethane, or polyethylene) or shape. $^{24-27}$

Straight plastic stents are thought to have a longer patency than pigtail plastic stents because they are much less resistant to flow. However, compared to the inner diameter, which limits the time to stent occlusion, the effect of stent shape does not seem as significant. Pigtail stents show lesser migration than straight stents because anchoring is well-maintained, ${ }^{20}$ there is less likelihood of food clinging because they have multiple drain holes on the side, unlike the flap of the straight type, and there is less likelihood of decreasing bile flow velocity when a distal part touches the duodenal wall after partial migration (Fig. 4).

\section{Scheduled stent exchange}

Unexpected stent occlusion may lead to recurrent jaundice and cholangitis, or even sepsis without immediate treatment, which may be life-threatening. The best known preventive measure is replacing the stent before it becomes occluded. ${ }^{28}$

The median patency of 10-Fr plastic stents is 4 to 5 months in general, and the risk of stent occlusion increases significantly after 3 months. Many centers recommend stent replacement every 3 months on a scheduled (not as needed) basis. ${ }^{29,30}$ However, this depends on underlying pathology, because stent occlusion is rare when death is imminent in patients with a malignant disease. ${ }^{6}$ Therefore, it seems wise to aggressively use this method in patients with benign diseases who require repeated stent replacement. ${ }^{31}$

\section{Antibiotics with or without choleretics}

As bacterial colonization was found to be the most important cause of biliary plastic stent occlusion, in vitro and in vivo studies have been conducted with various antibiotics; however, none were found to prolong stent patency. ${ }^{18}$ Attempts have been made to induce synergistic effects by combining antibiotics with choleretic agents such as ursodeoxycholic 

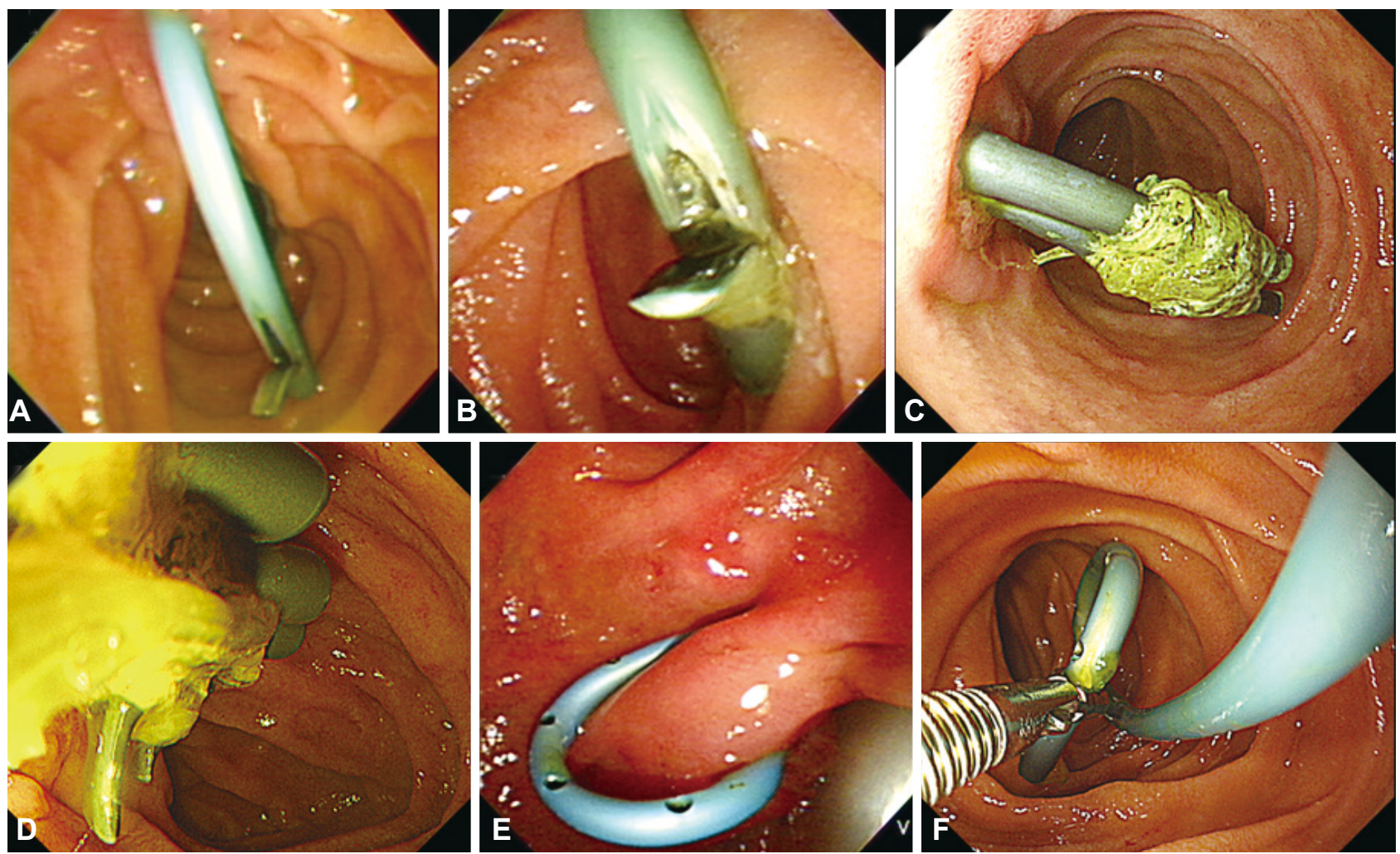

Fig. 4. Factors causing plastic biliary stent malfunction. $(A, B)$ Distal ends of the straight stents are touching the duodenal wall as a result of partial distal migration. This may lead to flow disturbance and sludge accumulation, causing occlusion. (C, D) The straight stents have not migrated, but dietary fibers are clinging to the side flaps, causing stent occlusion. (E, F) Distal ends of the pigtail stents are touching the duodenal wall or partially migrated, but the side holes still allow bile flow.

acid or terpene. However, the Cochrane review including a meta-analysis of 5 randomized trials reported no significant effect on stent patency or mortality rate. ${ }^{32}$

\section{Antibacterial coating or hydrophilic coating method}

Similar to antibiotic administration, studies evaluating stents that incorporate antibiotics failed to show prolonged patency with in vitro or pilot studies. ${ }^{33-35}$ These unfavorable results may be associated with technical issues such as inability to release antibiotics for a prolonged period of time, or because of bacterial resistance. ${ }^{6}$

In vitro experimental studies have demonstrated that Teflon stents with a low coefficient of friction or stents with a hydrophilic coating can inhibit bacterial colonization and sludge formation. ${ }^{36,37}$ Because bacterial adhesion to plastic stents is associated with surface hydrophobicity, studies have started to explore hydrophilic coatings. ${ }^{38-41}$ Earlier studies reporting promising results had received much attention as a breakthrough; however, subsequent prospective large-scale studies failed to show prolonged patency. ${ }^{42,43}$ The possible explanations are as follows: (1) the coated surface could have been damaged by guide wire manipulation during stent placement or by duodenobiliary reflux, and (2) the hydrophilic coating could have been degraded over time even before the initiation of stent occlusion.

In vitro studies were conducted to explore silver coating in the same context, but a clinical study has not been reported. $^{44,45}$

\section{Stent design: stent without side holes}

Many straight plastic stents have side holes created on purpose or added in the process of making the anti-migration flap. Coene and colleagues ${ }^{46}$ found that sludge accumulation was more frequent around side holes, and devised and studied a new stent without side holes. A known mechanism of increased encrustation of sludge around side holes is the creation of microturbulence, affecting the friction coefficient of bile flow. ${ }^{46,47}$ This observation stimulated other studies, but prolonged stent patency was not seen. ${ }^{24-26,48,49}$

\section{Stent design: antireflux valve}

The hypothesis that duodenobiliary reflux may induce biofilm or sludge formation has led to the introduction of a plastic stent with an antireflux valve. This plastic antireflux stent showed 1.5-times longer stent patency than the existing standard type ${ }^{50} \mathrm{~A}$ follow-up study used a similar antireflux plastic 
Table 1. Future Studies Needed to Improve Plastic Stent Patency

Development of self-expandable plastic stents, ensuring larger calibers

Development of bioabsorbable plastic stents, ensuring larger calibers

Development of new types of plastic stents with combined benefits of both straight and pigtail types

Development of special coating agents for the inner layer to prevent biofilm formation

Coating the inner surface with substances that can prevent surface irregularity caused by biofilm itself

Development of larger-diameter channel endoscopic retrograde cholangiopancreatography scope

Testing of single vs. multiple stents for malignant biliary obstruction

stent. ${ }^{51}$ Larger, prospective follow-up studies are needed.

An antireflux valve was also investigated with self-expandable metal stents (SEMS) with the same idea, but studies failed to show improved results. ${ }^{52-54}$ This was possibly because (1) the valve was deformed by gastroduodenal secretion, or (2) the valve was compressed by the duodenal wall as a result of bowel motion or partial migration, causing valve malfunctioning and bile flow disturbance, as is also expected with antireflux plastic stents.

\section{Stent position}

An animal study reported improved patency by placing a stent above the papilla, preventing bacterial colonization by food reflux from the intestine. ${ }^{55}$ This led to a prospective randomized study in humans, but the results showed increased stent migration rather than improved patency. ${ }^{56}$ This was also investigated with SEMS with the same idea, but again stent migration increased without improving patency. ${ }^{57}$

\section{CONCLUSIONS}

Endoscopic biliary stenting has been extensively investigated since the development of therapeutic endoscopy. For more than 30 years, however, no studies have produced any remarkable results to prolong stent patency, other than the implantation of larger-caliber stents or SEMS. As plastic biliary stents are easy to insert and remove, and financially less of a burden than SEMS, plastic stents with improved function to reduce occlusion are awaited. In the future, we also hope to see more studies on the following: (1) the development of self-expandable plastic stents or bioabsorbable plastic stents, ensuring larger calibers; (2) the development of new types of plastic stents with combined benefits of both straight and pigtail types, to eliminate the effect of food components on the flap without affecting flow velocity; (3) the development of new materials effective for preventing biofilm formation as a special coating agent on the inner surface; or (4) if it is not possible to inhibit biofilm effectively, methods of coating the inner surface with substances that can prevent surface irregularity caused by the biofilm itself, so that debris or sludge cannot be incorporated; (5) development of a larger-diameter channel ERCP scope; (6) testing of single versus multiple stents for routine malignant biliary obstruction (Table 1).

Conflicts of Interest

The authors have no financial conflicts of interest.

\section{Acknowledgments}

The following author received research support for this study from the Industrial Technology Innovation Program (Advanced Technology Center Program) funded by the Korean Ministry of Trade, Industry \& Energy: Chang-Il Kwon.

\section{REFERENCES}

1. Ballinger AB, McHugh M, Catnach SM, Alstead EM, Clark ML. Symptom relief and quality of life after stenting for malignant bile duct obstruction. Gut 1994;35:467-470.

2. Faigel DO. Preventing biliary stent occlusion. Gastrointest Endosc 2000;51:104-107.

3. Raijman I. Biliary and pancreatic stents. Gastrointest Endosc Clin N Am 2003;13:561-592.

4. Soehendra N, Reynders-Frederix V. Palliative bile duct drainage: a new endoscopic method of introducing a transpapillary drain. Endoscopy 1980;12:8-11.

5. Speer AG, Cotton PB, Russell RC, et al. Randomised trial of endoscopic versus percutaneous stent insertion in malignant obstructive jaundice. Lancet 1987;2:57-62.

6. Libby ED, Leung JW. Prevention of biliary stent clogging: a clinical review. Am J Gastroenterol 1996;91:1301-1308.

7. Leung JW, Liu Y, Chan RC, et al. Early attachment of anaerobic bacteria may play an important role in biliary stent blockage. Gastrointest Endosc 2000;52:725-729.

8. van Berkel AM, van Marle J, Groen AK, Bruno MJ. Mechanisms of biliary stent clogging: confocal laser scanning and scanning electron microscopy. Endoscopy 2005;37:729-734.

9. Guaglianone E, Cardines R, Vuotto C, et al. Microbial biofilms associated with biliary stent clogging. FEMS Immunol Med Microbiol 2010;59:410-420.

10. Groen AK, Out T, Huibregtse K, Delzenne B, Hoek FJ, Tytgat GN. Characterization of the content of occluded biliary endoprostheses. Endoscopy 1987;19:57-59.

11. Speer AG, Cotton PB, Rode J, et al. Biliary stent blockage with bacterial biofilm. A light and electron microscopy study. Ann Intern Med 1988;108:546-553. 
12. Leung JW, Ling TK, Kung JL, Vallance-Owen J. The role of bacteria in the blockage of biliary stents. Gastrointest Endosc 1988;34:19-22.

13. Moesch C, Sautereau D, Cessot F, et al. Physicochemical and bacteriological analysis of the contents of occluded biliary endoprostheses. Hepatology 1991;14:1142-1146.

14. An YH, Friedman RJ. Concise review of mechanisms of bacterial adhesion to biomaterial surfaces. J Biomed Mater Res 1998;43:338-348.

15. Chan FK, Suen M, Li JY, Sung JJ. Bile immunoglobulins and blockage of biliary endoprosthesis: an immunohistochemical study. Biomed Pharmacother 1998;52:403-407.

16. Yu JL, Andersson R, Ljungh A. Protein adsorption and bacterial adhesion to biliary stent materials. J Surg Res 1996;62:69-73.

17. Yu JL, Andersson R, Wang LQ, Bengmark S, Ljungh A. Fibronectin on the surface of biliary drain materials: a role in bacterial adherence. J Surg Res 1995;59:596-600.

18. Donelli G, Guaglianone E, Di Rosa R, Fiocca F, Basoli A. Plastic biliary stent occlusion: factors involved and possible preventive approaches. Clin Med Res 2007;5:53-60.

19. Speer AG, Cotton PB, MacRae KD. Endoscopic management of malignant biliary obstruction: stents of 10 French gauge are preferable to stents of 8 French gauge. Gastrointest Endosc 1988;34:412-417.

20. ASGE Technology Assessment Committee, Pfau PR, Pleskow DK, et al. Pancreatic and biliary stents. Gastrointest Endosc 2013;77:319-327.

21. Gilbert DA, DiMarino AJ Jr, Jensen DM, et al. Status evaluation: biliary stents. American Society for Gastrointestinal Endoscopy. Technology Assessment Committee. Gastrointest Endosc 1992;38:750-752.

22. Kadakia SC, Starnes E. Comparison of 10 French gauge stent with 11.5 French gauge stent in patients with biliary tract diseases. Gastrointest Endosc 1992;38:454-459.

23. Wagh MS, de Bellis M, Fogel EL, et al. Multicenter randomized trial of 10-French versus 11.5-French plastic stents for malignant biliary obstruction. Diagn Ther Endosc 2013;2013:891915.

24. van Berkel AM, Boland C, Redekop WK, et al. A prospective randomized trial of Teflon versus polyethylene stents for distal malignant biliary obstruction. Endoscopy 1998;30:681-686.

25. England RE, Martin DF, Morris J, et al. A prospective randomised multicentre trial comparing $10 \mathrm{Fr}$ Teflon Tannenbaum stents with $10 \mathrm{Fr}$ polyethylene Cotton-Leung stents in patients with malignant common duct strictures. Gut 2000;46:395-400

26. Terruzzi V, Comin U, De Grazia F, et al. Prospective randomized trial comparing Tannenbaum Teflon and standard polyethylene stents in distal malignant biliary stenosis. Gastrointest Endosc 2000;51:23-27.

27. Cheon YK, Oh HC, Cho YD, Lee TY, Shim CS. New 10F soft and pliable polyurethane stents decrease the migration rate compared with conventional $10 \mathrm{~F}$ polyethylene stents in hilar biliary obstruction: results of a pilot study. Gastrointest Endosc 2012;75:790-797.

28. Motte S, Deviere J, Dumonceau JM, Serruys E, Thys JP, Cremer M. Risk factors for septicemia following endoscopic biliary stenting. Gastroenterology 1991;101:1374-1381.

29. Shepherd HA, Royle G, Ross AP, Diba A, Arthur M, Colin-Jones D. Endoscopic biliary endoprosthesis in the palliation of malignant obstruction of the distal common bile duct: a randomized trial. Br J Surg 1988;75:1166-1168.

30. Schmassmann A, von Gunten E, Knuchel J, Scheurer U, Fehr HF, Halter F. Wallstents versus plastic stents in malignant biliary obstruction: effects of stent patency of the first and second stent on patient compliance and survival. Am J Gastroenterol 1996;91:654-659.

31. Kwon CI, Ko KH, Hahm KB, Kang DH. Functional self-expandable metal stents in biliary obstruction. Clin Endosc 2013;46:515-521.

32. Galandi D, Schwarzer G, Bassler D, Allgaier HP. Ursodeoxycholic acid and/or antibiotics for prevention of biliary stent occlusion. Cochrane Database Syst Rev 2002;(3):CD003043.

33. Browne, S, Schmalz, M, Geenen, J, Venu, R, Johnson, GK. A comparison of biliary and pancreatic stent occlusion in antibiotic-coated vs. conventional stents. Gastrointest Endosc 1990;36:206.
34. Gwon DI, Lee SS, Kim EY. Cefotaxime-eluting covered self-expandable stents in a canine biliary model: scanning electron microscopic study of biofilm formation. Acta Radiol 2012;53:1127-1132.

35. Weickert U, Wiesend F, Subkowski T, Eickhoff A, Reiss G. Optimizing biliary stent patency by coating with hydrophobin alone or hydrophobin and antibiotics or heparin: an in vitro proof of principle study. Adv Med Sci 2011;56:138-144.

36. Dowidar N, Kolmos HJ, Matzen P. Experimental clogging of biliary endoprostheses. Role of bacteria, endoprosthesis material, and design. Scand J Gastroenterol 1992;27:77-80.

37. Jansen B, Goodman LP, Ruiten D. Bacterial adherence to hydrophilic polymer-coated polyurethane stents. Gastrointest Endosc 1993;39:670673.

38. Sung JY, Shaffer EA, Lam K, Rususka I, Costerton JW. Hydrophobic bile salt inhibits bacterial adhesion on biliary stent material. Dig Dis Sci 1994;39:999-1006.

39. John SF, Hillier VF, Handley PS, Derrick MR. Adhesion of staphylococci to polyurethane and hydrogel-coated polyurethane catheters assayed by an improved radiolabelling technique. J Med Microbiol 1995;43:133-140.

40. McAllister EW, Carey LC, Brady PG, Heller R, Kovacs SG. The role of polymeric surface smoothness of biliary stents in bacterial adherence, biofilm deposition, and stent occlusion. Gastrointest Endosc 1993;39:422-425.

41. Hoffman BJ, Cunningham JT, Marsh WH, O'Brien JJ, Watson J. An in vitro comparison of biofilm formation on various biliary stent materials. Gastrointest Endosc 1994;40:581-583.

42. van Berkel AM, Bruno MJ, Bergman JJ, van Deventer SJ, Tytgat GN, Huibregtse K. A prospective randomized study of hydrophilic polymer-coated polyurethane versus polyethylene stents in distal malignant biliary obstruction. Endoscopy 2003;35:478-482.

43. Costamagna G, Mutignani M, Rotondano G, et al. Hydrophilic hydromer-coated polyurethane stents versus uncoated stents in malignant biliary obstruction: a randomized trial. Gastrointest Endosc 2000;51:811.

44. Leung JW, Lau GT, Sung JJ, Costerton JW. Decreased bacterial adherence to silver-coated stent material: an in vitro study. Gastrointest Endosc 1992;38:338-340.

45. Yang J, Linghu E, Wang Y. Development of antibacterial plastic biliary stent coated with nano-silver. Zhongguo Yi Liao Qi Xie Za Zhi 2011;35:352-355, 360. Chinese.

46. Coene PP, Groen AK, Cheng J, Out MM, Tytgat GN, Huibregtse K. Clogging of biliary endoprostheses: a new perspective. Gut 1990;31:913917.

47. Rey JF, Maupetit P, Greff M. Experimental study of biliary endoprosthesis efficiency. Endoscopy 1985;17:145-148.

48. Seitz U, Vadeyar H, Soehendra N. Prolonged patency with a new-design Teflon biliary prosthesis. Endoscopy 1994;26:478-482.

49. Binmoeller KF, Seitz U, Seifert H, Thonke F, Sikka S, Soehendra N. The Tannenbaum stent: a new plastic biliary stent without side holes. Am J Gastroenterol 1995;90:1764-1768.

50. Dua KS, Reddy ND, Rao VG, Banerjee R, Medda B, Lang I. Impact of reducing duodenobiliary reflux on biliary stent patency: an in vitro evaluation and a prospective randomized clinical trial that used a biliary stent with an antireflux valve. Gastrointest Endosc 2007;65:819-828.

51. Leong QW, Shen ML, Au KW, et al. A prospective, randomized study of the patency period of the plastic antireflux biliary stent: an interim analysis. Gastrointest Endosc 2016;83:387-393.

52. Lee YN, Moon JH, Choi HJ, et al. Effectiveness of a newly designed antireflux valve metal stent to reduce duodenobiliary reflux in patients with unresectable distal malignant biliary obstruction: a randomized, controlled pilot study (with videos). Gastrointest Endosc 2016;83:404412.

53. Hu B, Wang TT, Wu J, Shi ZM, Gao DJ, Pan YM. Antireflux stents to reduce the risk of cholangitis in patients with malignant biliary strictures: a randomized trial. Endoscopy 2014;46:120-126. 


\section{Ce cumcal Enosscopy}

54. Kim DU, Kwon CI, Kang DH, Ko KH, Hong SP. New antireflux self-expandable metal stent for malignant lower biliary obstruction: in vitro and in vivo preliminary study. Dig Endosc 2013;25:60-66.

55. Georghegan JG, Branch MS, Costerton JW, Pappas TN, Cotton PB. Placement of biliary stents above the sphincter of Oddi prolongs stent patency in dogs. Gut 1991;32:A1232.

56. Pedersen FM, Lassen AT, Schaffalitzky de Muckadell OB. Randomized trial of stent placed above and across the sphincter of Oddi in malignant bile duct obstruction. Gastrointest Endosc 1998;48:574-579.

57. Cho JN, Han J, Kim HG, et al. Prospective randomized trial comparing covered metal stent placed above and across the sphincter of Oddi in malignant biliary obstruction. Gastrointest Endosc 2013;77(5 Suppl):AB139-AB140. 